\title{
Differential Effects of Cancer-Associated Mutations Enriched in Helix $\mathrm{H} 3$ of PPAR $\gamma$
}

\author{
Dong Man Jang ${ }^{1,+} \mathbb{C}$, Jun Young Jang ${ }^{1,+}$, Hyun-Jung Kim ${ }^{2}$ and Byung Woo Han ${ }^{1, *(\mathbb{D}}$ \\ 1 Research Institute of Pharmaceutical Sciences, College of Pharmacy, Seoul National University, Seoul 08826, \\ Korea; jdm721@snu.ac.kr (D.M.J.); nosvc4@snu.ac.kr (J.Y.J.) \\ 2 College of Pharmacy, Chung-Ang University, Seoul 06974, Korea; hyunjungkim@cau.ac.kr \\ * Correspondence: bwhan@snu.ac.kr; Tel.: +82-2-880-7898 \\ + These authors contributed equally to this work.
}

Received: 2 November 2020; Accepted: 27 November 2020; Published: 30 November 2020

check for updates

Simple Summary: The high frequency of mutations in helix H3 of the peroxisome proliferator-activated receptor gamma (PPAR $\gamma$ ) ligand-binding domain (LBD) in various cancers suggest that this region has an important role in tumorigenesis. In this study, we performed bioinformatics, structural and biochemical analyses to characterize PPAR $\gamma$ LBDs with helix H3 mutations found in cancers. In the absence of ligands, PPAR $\gamma$ Q286E that was a mutation found in patients with bladder cancer induced a constitutively active conformation of PPAR $\gamma$ and promoted coactivator recruitment, providing evidence for tumorigenic effects. A number of other mutations reduced PPAR $\gamma$ activation by various mechanisms. Accordingly, mutations in helix H3 of PPAR $\gamma$ LBD have a wide range of effects and are key candidates for the development of biomarkers and targeted therapies.

\begin{abstract}
Peroxisome proliferator-activated receptor gamma (PPAR $\gamma$ ) has recently been revealed to regulate tumor microenvironments. In particular, genetic alterations of PPAR $\gamma$ found in various cancers have been reported to play important roles in tumorigenesis by affecting PPAR $\gamma$ transactivation. In this study, we found that helix H3 of the PPAR $\gamma$ ligand-binding domain (LBD) has a number of sites that are mutated in cancers. To uncover underlying molecular mechanisms between helix H3 mutations and tumorigenesis, we performed structure-function studies on the PPAR $\gamma$ LBDs containing helix H3 mutations found in cancers. Interestingly, PPAR $\gamma$ Q286E found in bladder cancer induces a constitutively active conformation of PPAR $\gamma$ LBD and thus abnormal activation of PPAR $\gamma / R X R \alpha$ pathway, which suggests tumorigenic roles of PPAR $\gamma$ in bladder cancer. In contrast, other helix $\mathrm{H} 3$ mutations found in various cancers impair ligand binding essential for transcriptional activity of PPAR $\gamma$. These data indicate that cancer-associated mutations clustered in helix $\mathrm{H} 3$ of PPAR $\gamma$ LBD exhibit differential effects in PPAR $\gamma$-mediated tumorigenesis and provide a basis for the development of new biomarkers targeting tumor microenvironments.
\end{abstract}

Keywords: cancer mutation; helix H3; ligand-binding domain; PPAR $\gamma$; tumor microenvironment

\section{Introduction}

Peroxisome proliferator-activated receptor gamma (PPAR $\gamma$ ) belonging to thyroid hormone receptor-like nuclear receptor subfamily 1 is a ligand-inducible transcription factor [1]. PPAR $\gamma$ forms a heterodimer with retinoid $X$ receptor $\alpha(R X R \alpha)$, recruits various co-regulators and regulates the expression of downstream target proteins [2]. The transcriptional regulation of PPAR $\gamma$ plays an important role in adipogenesis, insulin sensitization, lipid metabolism, glucose homeostasis and inflammation [3,4]. Thus, PPAR $\gamma$ is a target for the treatment of metabolic diseases, including type 2 
diabetes, obesity and atherosclerosis [5]. In fact, PPAR $\gamma$ full agonist thiazolidinedione (TZD) drugs, such as pioglitazone and rosiglitazone, have been widely used for the treatment of diabetes, despite known side effects, such as weight gain, fluid retention and bone loss [6-8].

Recently, PPAR $\gamma$ has emerged as a mediator of tumor microenvironments [9,10]. There is accumulating evidence for tumorigenic roles of PPAR $\gamma$ in a variety of cancers, including colon, breast, lung, prostate and bladder cancers [5,11]. In general, activation of PPAR $\gamma$ by agonists exerts inhibitory effects on tumor growth by various mechanisms, including apoptosis, cell cycle arrest and inhibitions of angiogenesis or differentiation [12-15]. For example, PPAR $\gamma$ activation has been known to inhibit the expression of angiogenesis-associated proteins, such as basic fibroblast growth factor (bFGF) and vascular endothelial growth factor (VEGF) $[9,16,17]$. Moreover, TZD drugs elicit tumor-suppressive effects to induce apoptosis and inhibit cell proliferation in various cancer cells by regulating apoptosis-associated proteins, such as cyclooxygenase-2 (COX-2), B-cell lymphoma 2 (Bcl-2), epidermal growth factor receptor (EGFR) and Fas ligand (FasL) [18-22]. In a recent study, lung cancer cells treated with PPAR $\gamma$ agonists remarkably lost migratory and invasive properties essential for cancer metastasis [10]. Furthermore, there have been clinical trials for various cancers using PPAR $\gamma$ agonists such as pioglitazone [23].

In addition to the pharmacological regulation of PPAR $\gamma$ in cancers, PPARG genetic alterations resulting in a loss- or gain-of-function have been reported in a variety of cancer types [24,25]. Due to the tumor-suppressive effect of PPAR $\gamma$, some loss-of-function mutations in PPARG have been regarded as tumorigenic factors [26,27]. Indeed, somatic PPARG loss-of-function mutations decrease the transcriptional activity of PPAR $\gamma$ by inhibiting ligand binding in sporadic colon cancer [24]. In addition, a PPARG germline mutation found in a patient with colorectal cancer impairs the transactivation potential and impedes agonist positioning [28]. On the other hand, gain-of-function mutations in PPARG have also been found in cancers [25,29]. Some recurrent PPARG mutations in luminal bladder cancer increase the ligand-independent transcriptional activity of PPAR $\gamma$, resulting in the upregulation of PPAR $\gamma$ target genes $[25,29]$. The activation of the PPAR $\gamma / R X R \alpha$ pathway as a result of gain-of-function mutations impairs $\mathrm{CD} 8^{+} \mathrm{T}$-cell infiltration by inhibiting the expression and secretion of inflammatory cytokines and confers acquired resistance to immunotherapies [30]. Owing to the ongoing discovery of PPARG mutations in various cancers, the molecular basis of PPAR $\gamma$ mutations found in cancers would be an emerging topic of great importance.

Helix $\mathrm{H} 3$ of the PPAR $\gamma$ ligand-binding domain (LBD) is essential for ligand binding and PPAR $\gamma$ activation and harbors a relatively large number of sites that are mutated in cancers. In this study, to identify the functional relationship between mutations in helix H3 of PPAR $\gamma$ LBD and cancer development or progression, structural and biochemical analyses were performed using crystal structures and in vitro assays for $\mathrm{RXR} \alpha$ dimerization, coactivator recruitment and transcriptional activity. In addition, we measured binding affinities between PPAR $\gamma$ LBD mutants and endogenous ligands. Our results reveal differential effects of the helix H3 mutations in PPAR $\gamma$ transcriptional activity and provide a molecular mechanism underlying PPAR $\gamma$-mediated tumorigenesis.

\section{Results}

\subsection{Structural Comparison of PPAR $\gamma$ LBDs Containing Helix H3 Mutations Found in Various Cancers}

Using the cBioPortal and COSMIC servers [31-33], we obtained 45,665 cancer samples from publicly available databases, such as The Cancer Genome Atlas (TCGA) and International Cancer Genome Consortium (ICGC). Among 282 mutation samples in PPAR $\gamma$, we focused on 189 missense mutations. Interestingly, we found that helix $\mathrm{H} 3$ of PPAR $\gamma$ LBD is enriched for mutations that are found in cancers; helix H3 accounts for only $9.4 \%$ of the amino acids in the PPAR $\gamma$ LBD but $19.6 \%$ of PPAR $\gamma$ LBD mutations found in cancers (19 mutations in helix H3 among 97 mutations distributed in the PPAR $\gamma$ LBD). Because it might provide insight into the mechanisms underlying PPAR $\gamma$-mediated tumorigenesis, we focused on mutations in helix $\mathrm{H} 3$ of PPAR $\gamma$ LBD for further structure-function 
analyses. In addition to the mutation data from bioinformatics analyses, we added two helix $\mathrm{H} 3$ mutations of apo PPAR $\gamma$ LBD (Q286P and S289C) reported in literatures [24,28]. We determined the crystal structures of PPAR $\gamma$ LBDs containing helix H3 mutations found in cancer patients at $1.9 \AA$ to $2.7 \AA$ resolution with or without an SRC-1 peptide, which are monomeric or dimeric in an asymmetric unit, respectively (Table S1). The mutations in helix H3 of PPAR $\gamma$ LBD included C285Y, Q286P, R288H and S289C identified in patients with colorectal cancer, F287Y, R288C from patients with skin cancer, Q286E from a patient with bladder cancer and R280C from a patient with uterine cancer (Figure 1A and Table S2). The structures of PPAR $\gamma$ LBD wild-type (WT) and mutants adopted a general nuclear receptor fold comprising one bundle of $13 \alpha$-helices and one four-stranded $\beta$-sheet (Figure 1B). In the mutant structures, the mutant residues were well-modeled (Figure $1 \mathrm{C}$ and Figure S1). The overall structures of apo PPAR $\gamma$ LBD WT and mutants were nearly identical with root-mean-square deviation (RMSD) values of $0.20 \AA$ (R280C), $0.43 \AA$ (C285Y), $0.65 \AA$ (Q286E), $0.27 \AA$ (F287Y), $0.31 \AA$ (R288C), 0.29 $\AA$ (R288H) and $0.29 \AA$ (S289C) over $260 \mathrm{C}_{\alpha}$ atom pairs of chain A (Figure $1 \mathrm{D}$ and Figure S2). However, noticeable structural differences in the mutants were observed in the H2- $\beta 1$ loop, $\Omega$-loop (a loop between $\mathrm{H} 2$ ' and $\mathrm{H} 3$ ), helix $\mathrm{H} 3$ and H11-H12 loop with relatively high $\mathrm{C}_{\alpha}$ RMSD values (Figure 1D). In particular, the $\Omega$-loop was the most flexible region in the structure of PPAR $\gamma$ LBD; hence, it was only partially modeled in some of the mutant structures (Figure 1D). Since the PPAR $\gamma$ LBD Q286P mutant could not be crystallized, we analyzed secondary structural elements by circular dichroism (CD) experiments. Based on the CD spectra of PPAR $\gamma$ LBD WT, Q286P and Q286E, the overall structure of PPAR $\gamma$ LBD Q286P would resemble those of PPAR $\gamma$ LBD WT and Q286E (Figure S3).

\subsection{PPAR $\gamma$ LBD Q286E Induces a Constitutively Active Conformation of PPAR $\gamma$ LBD}

Among the crystal structures of 7 PPAR $\gamma$ LBD mutants, the structure of PPAR $\gamma$ LBD Q286E exhibited the highest $\mathrm{C}_{\alpha}$ RMSD value, which was mainly caused by the $\mathrm{H} 2^{\prime}-\mathrm{H} 3$ and $\mathrm{H} 11-\mathrm{H} 12$ regions (Figure 1D). Accordingly, we intensively compared the structures of PPAR $\gamma$ LBD Q286E and WT (Figure 2A). To our surprise, the mutated Glu286 residue on helix H3 directly stabilized helix H12 and induced a constitutively active form of PPAR $\gamma$ (Figure 2B). In particular, the $\mathrm{O}_{\varepsilon}$ atom of Glu286 formed hydrogen bonds with the $\mathrm{O}_{\eta}$ atom of Tyr473 in helix H12 and the $\mathrm{N}_{\varepsilon}$ atom of His449 in helix H11 with distances of $2.7 \AA$ and $3.1 \AA$, respectively, unlike the WT structure with an interaction between Gln286 and Leu465 in the H11-H12 loop (Figure 2B). The interaction network inducing the constitutively active form of PPAR $\gamma$ was observed in the PPAR $\gamma$ Q286E mutant in the presence and absence of an SRC-1 peptide (Figure 2A and Figure S4). In addition, to examine whether the structural conformation of Glu286 interacting with Tyr473 in helix H12 exists in solution, we implemented a surface plasmon resonance (SPR) experiment using a synthetic ligand, lobeglitazone known as a full agonist interacting with Tyr473 [34]. In the SPR analysis, the binding affinity of lobeglitazone for PPAR $\gamma$ LBD was lower in the Q286E mutant $\left(K_{\mathrm{D}}=52 \mathrm{nM}\right)$ than in PPAR $\gamma$ WT $\left(K_{\mathrm{D}}=18 \mathrm{nM}\right)$ (Figure 2C). The inhibitory effect of the Q286E mutation on lobeglitazone binding to PPAR $\gamma$ implies that the constitutively active conformation of PPAR $\gamma$ Q286E upon the interaction between Glu286 and Tyr473 is physiologically relevant. 
A

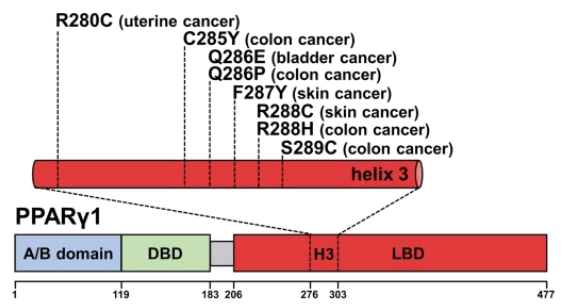

B

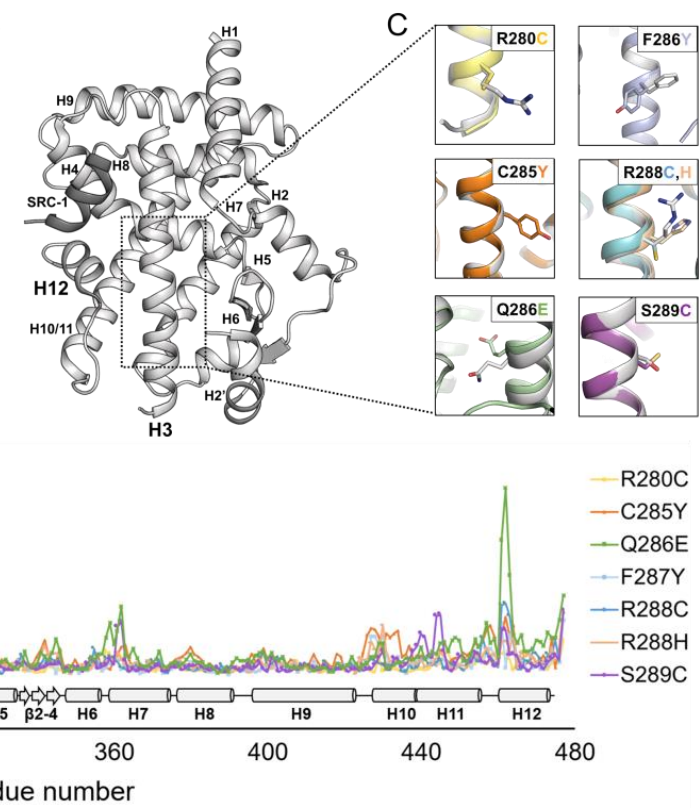

Figure 1. The helix H3 mutations of PPAR $\gamma$ ligand-binding domain (LBD) found in cancers and their crystal structures. (A) Schematic diagrams displaying domain compositions and mutations in helix $\mathrm{H} 3$ of PPAR $\gamma$ LBD. Sequences are numbered according to the PPAR $\gamma 1$ isoform. A/B domain, DBD and LBD indicate N-terminal domain, DNA-binding domain and ligand-binding domain, respectively. (B) Overall structure of PPAR $\gamma$ LBD WT displayed as a cartoon representation colored in light grey. A SRC-1 peptide is colored in dark grey. (C) The structural comparisons of apo PPAR $\gamma$ LBD WT and mutants. The structure of PPAR $\gamma$ LBD WT is superposed with those of PPAR $\gamma$ LBD mutants. The side chains of the WT and mutated residues are shown as stick representations, in light grey color for the WT and various colors for the mutants. (D) The comparison of $C_{\alpha}$ RMSD values for the PPAR $\gamma$ LBD mutant structures against the PPAR $\gamma$ LBD WT structure. The mutant structures of PPAR $\gamma$ LBD R280C, C285Y, Q286E, F287Y, R288C, R288H and S289C are compared to the PPAR $\gamma$ LBD WT structure in the presence of a SRC-1 peptide (PDB ID: 6JQ7). Secondary structure elements are displayed along residue numbers. 

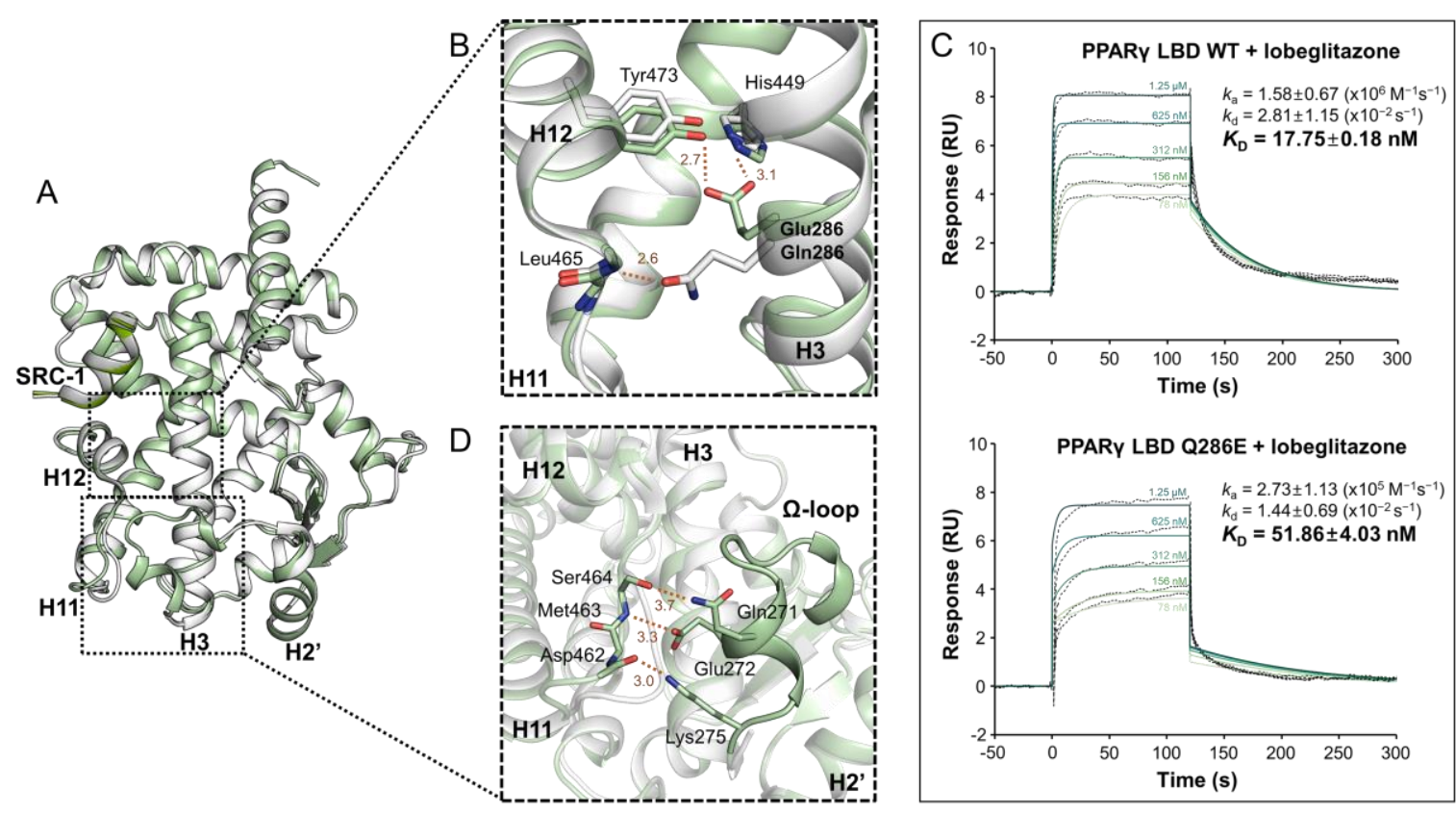

Figure 2. Overall structures of PPAR $\gamma$ LBD WT and Q286E. (A) Superposition of apo PPAR $\gamma$ LBD WT (white) and Q286E (pale green) structures. Overall structures are displayed as cartoon representations. (B) The region of helices H3, H11 and H12 is magnified and depicted by a black-dashed box. Stick representations are shown for the backbone of Leu465 and the side chains of Tyr473, His449, Glu286 of Q286E and Gln286 of WT. (C) Surface plasmon resonance (SPR) analyses of binding affinities for lobeglitazone of PPAR $\gamma$ LBD WT (upper) and Q286E (bottom). SPR sensorgrams show the binding of lobeglitazone at increasing concentrations to immobilized proteins of PPAR $\gamma$ LBD WT and Q286E. $K_{D}$ values shown on the right side are calculated from fitting (colored lines) onto the responses (dotted lines in black color). The data of $k_{\mathrm{a}}, k_{\mathrm{d}}$ and $K_{\mathrm{D}}$ are presented as the mean $\pm \mathrm{SD}$ of two independent experiments. (D) The region of $\Omega$-loop is magnified and depicted by a black-dashed box. Stick representations are shown for the side chains of Gln271, Glu272, Lys275 and Ser464 and the backbones of Asp462 and Met463 in the PPAR $\gamma$ Q286E structure. Hydrogen bonds are depicted by orange dashed lines and labeled with distances in $\AA$. Oxygen and nitrogen atoms are colored in red and blue, respectively.

Another remarkable structural feature of the PPAR $\gamma$ LBD Q286E mutant is the well-defined $\Omega$-loop with a helical structure, considering that the $\Omega$-loop in the structures of PPAR $\gamma$ LBD WT and other mutants could not be modeled owing to its high flexibility (Figure 2D). The $\Omega$-loop of the PPAR $\gamma$ LBD Q286E structure was stabilized by creating an extensive interaction network with an H11-H12 loop via hydrogen bonds (Figure 2D). In particular, Gln271, Glu272 and Lys275 on the $\Omega$-loop establish hydrogen bonds with the side chain of Ser464 and backbones of Met463 and Asp462 with distances of $3.3 \AA, 3.0 \AA$ and $3.0 \AA$, respectively (Figure 2D). Moreover, the side chain of Glu272 on the $\Omega$-loop formed a hydrogen bond with the side chain of Gln283 on helix H3 with a distance of $2.9 \AA$ (Figure S5). The stabilization of $\Omega$-loop was also observed in the structure of PPAR $\gamma$ LBD Q286E chain B in the absence of an SRC-1 peptide (Figure S6). Taken together, the interaction network among the $\Omega$-loop, the H11-H12 loop and helix H3 induce structural stabilization in PPAR $\gamma$ Q286E, resulting in the constitutively active conformation.

\subsection{PPAR $\gamma$ Q286E Recruits RXR $\alpha$ and MED1 with High Affinities}

The transcriptional activity of PPAR $\gamma$ is regulated by heterodimer formation with RXR $\alpha$ and the recruitment of co-regulators [2]. To evaluate the effect of mutations on transcriptional activity, we quantified heterodimerization between PPAR $\gamma$ LBD and RXR $\alpha$ LBD by SPR (Figure 3A-C and 
Figure S7). After RXR $\alpha$ LBD was immobilized on the CM5 sensor chip, PPAR $\gamma$ LBD WT and mutant proteins were injected over the chip at concentrations ranging from $1.56 \mathrm{nM}$ to $100 \mathrm{nM}$, respectively. The equilibrium dissociation constant $\left(K_{\mathrm{D}}\right)$ of PPAR $\gamma$ LBD WT for RXR $\alpha$ LBD was $57.85 \mathrm{nM}$, based on a $k_{\mathrm{a}}$ value of $3.96 \times 10^{5} \mathrm{M}^{-1} \mathrm{~s}^{-1}$ and $k_{\mathrm{d}}$ value of $2.23 \times 10^{-2} \mathrm{~s}^{-1}$ (Figure 3A). To our surprise, PPAR $\gamma$ LBD Q286E exhibited a two-fold higher binding affinity for RXR $\alpha$ LBD with a $K_{\mathrm{D}}$ value of $26.52 \mathrm{nM}$, even though Glu286 was not located on the heterodimeric interface (Figure 3B). Interestingly, the high binding affinity of PPAR $\gamma$ LBD Q286E for RXR $\alpha$ LBD could be explained by the slow dissociation rate rather than by a fast association rate (Figure 3B). On the other hand, the PPAR $\gamma$ LBD R280C, C285Y, F287Y, R288H and S289C mutants exhibited similar binding affinities for RXR $\alpha$ LBD to that of PPAR $\gamma$ LBD WT, while the PPAR $\gamma$ LBD Q286P and R288C mutants exhibited lower binding affinities, with $K_{\mathrm{D}}$ values of $122.4 \mathrm{nM}$ and $136.9 \mathrm{nM}$, respectively (Figure 3C).

A

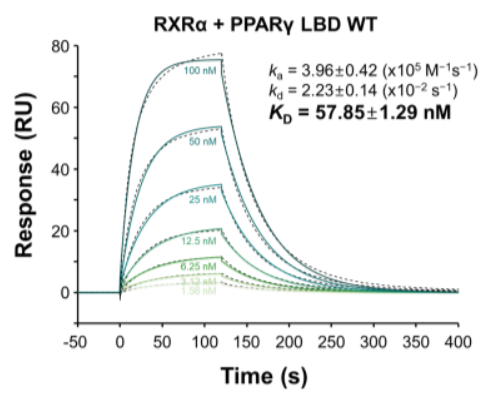

D

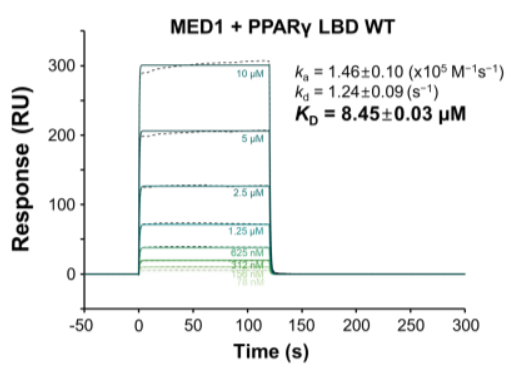

B

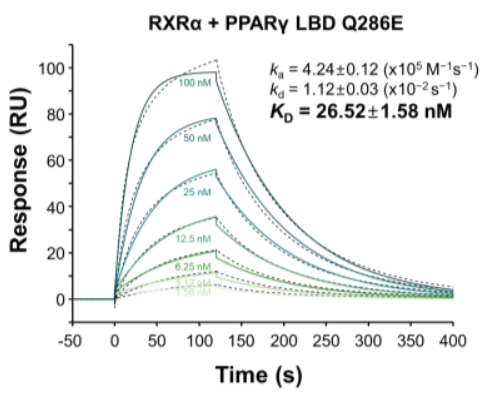

E

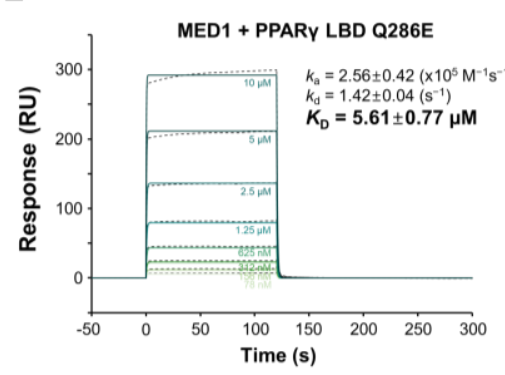

C

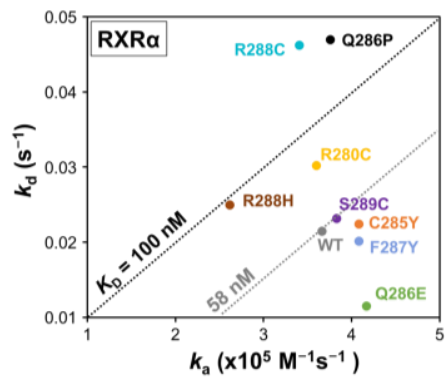

F

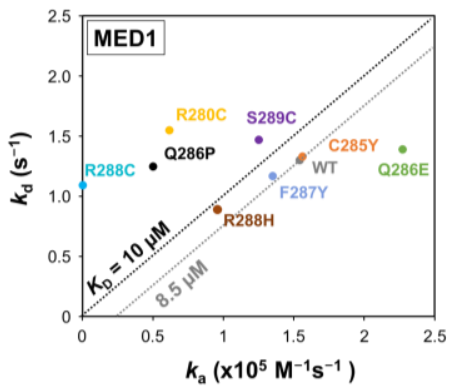

Figure 3. Binding affinities of PPAR $\gamma$ LBD WT and mutants for RXR $\alpha$ and MED1. (A,B) SPR sensorgrams for interactions of RXR $\alpha$ LBD with PPAR $\gamma$ LBD WT (A) and Q286E (B). SPR sensorgrams show the binding of PPAR $\gamma$ LBD proteins at increasing concentrations to immobilized RXR $\alpha$ LBD. (D,E) Sensorgrams for interactions of MED1 peptide with PPAR $\gamma$ LBD WT (D) and Q286E (E). SPR sensorgrams show the binding of PPAR $\gamma$ LBD proteins at increasing concentrations to immobilized MED1 peptides. The equilibrium dissociation constant $\left(K_{\mathrm{D}}\right)$ shown on the right side is calculated by fitting (colored lines) the responses (dotted lines in black color). The data of $k_{\mathrm{a}}, k_{\mathrm{d}}$ and $K_{\mathrm{D}}$ are presented as the mean \pm SD of two independent experiments. (C,F) Summary of $K_{D}$ values for PPAR $\gamma$ LBD with $\mathrm{RXR} \alpha \mathrm{LBD}(\mathbf{C})$ and MED1 peptides (F). A $K_{\mathrm{D}}$ value is obtained from dividing the dissociation rate $\left(k_{\mathrm{d}}\right)$ of $\mathrm{Y}$-axis by the association rate $\left(k_{\mathrm{a}}\right)$ of $\mathrm{X}$-axis. The black- and grey-dashed diagonal lines represent a $K_{\mathrm{D}}$ value for a standard and a $K_{\mathrm{D}}$ value for the $\mathrm{WT}$, respectively.

Next, we evaluated the interaction between PPAR $\gamma$ LBD and MED1 co-activator peptides containing the LXXLL motif, where $X$ represents any amino acid residue, by SPR (Figure 3D-F and Figure S8). PPAR $\gamma$ LBD WT and mutants at concentrations of $78 \mathrm{nM}$ to $10 \mu \mathrm{M}$ were injected over the MED1 peptide-immobilized CM5 chip. The equilibrium dissociation constant $\left(K_{\mathrm{D}}\right)$ of PPAR $\gamma$ LBD WT for the MED1 peptide was $8.45 \mu \mathrm{M}$, calculated from a $k_{\mathrm{a}}$ value of $1.46 \times 10^{5} \mathrm{M}^{-1} \mathrm{~s}^{-1}$ and $k_{\mathrm{d}}$ value of $1.24 \mathrm{~s}^{-1}$ (Figure 3D). The PPAR $\gamma$ LBD Q286E mutant exhibited a slightly higher binding affinity for the MED1 peptide $\left(K_{D}=5.61 \mu \mathrm{M}\right)$ than that of PPAR $\gamma$ LBD WT (Figure 3E), while the other mutants exhibited similar or lower binding affinities for the MED1 peptide (Figure 3F). These results 
demonstrate that the PPAR $\gamma$ Q286E mutation favors the recruitment of RXR $\alpha$ and MED1, which are essential for transcriptional activity, unlike the other mutants.

\subsection{PPAR $\gamma$ Q286E Exhibits Higher Transcriptional Activity than That of PPAR $\gamma$ LBD WT}

To further elucidate correlations between biophysical and biochemical characteristics described above and functional activity, we conducted cell-based luciferase assays to measure the transcriptional activity of PPAR $\gamma$. Transcriptional activities of full-length PPAR $\gamma$ WT and mutants in HEK293T cells were measured using a luciferase reporter vector fused to three copies of the PPAR $\gamma$ response element (PPRE) sequence and a normalization vector containing a Renilla luciferase gene. The transcriptional activity of PPAR $\gamma$ Q286E was significantly higher than that of PPAR $\gamma$ WT (Figure 4A). The PPAR $\gamma$ C285Y, F287Y and S289C mutants showed slightly higher transcriptional activities than that of PPAR $\gamma$ WT, whereas the R280C, Q286P and R288C mutations did not alter transcriptional activity (Figure 4A).

A

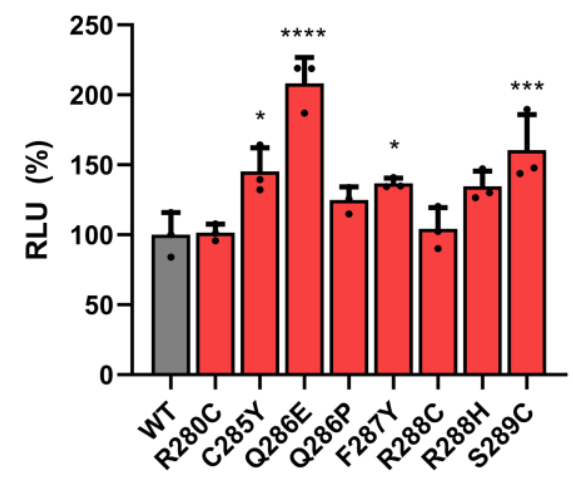

B

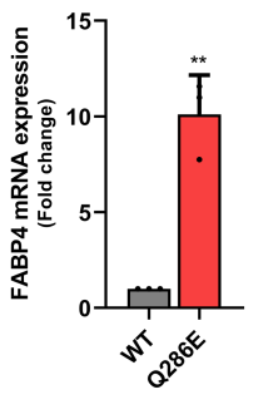

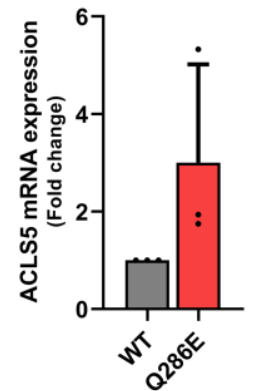

Figure 4. Transcriptional activity of PPAR $\gamma$ WT and mutants. (A) An expression vector encoding PPAR $\gamma$ full length WT or mutants (R280C, C285Y, Q286E, Q286P, F287Y, R288C, R288H and S289C) and a firefly luciferase reporter vector fused with three copies of PPAR $\gamma$ response element (PPRE) sequence are co-expressed in HEK293T cells with a normalization vector containing a Renilla luciferase gene. The firefly luciferase signals normalized by Renilla luciferase signals are indicated by relative luminescence unit (RLU, \%) to PPAR $\gamma$ WT. The data are presented as the mean \pm standard deviation (SD) of three independent experiments. The results for each mutant are compared to that for the WT in Dunnett's multiple comparison test, ${ }^{*} 0.01<p<0.05$; ${ }^{* * *} 0.0001<p<0.001$; ${ }^{* * * *} p<0.0001$. (B) The effects of PPAR $\gamma$ WT and Q286E expressions on three PPAR $\gamma$ target genes (FABP4, PLIN2 and $A C L S 5)$ are measured by RT-qPCR. The expression of PPAR $\gamma$ target genes is normalized against the basal expression of human $60 \mathrm{~S}$ ribosomal protein $L 32$. The data are presented as the mean \pm SD of three independent experiments. The result for the Q286E is compared with that for the WT in Student's $t$-test, ${ }^{*} 0.01<p<0.05 ; * * 0.01$.

To further investigate how the PPAR $\gamma$ Q286E mutation affects the expression of PPAR $\gamma$ target genes, mRNA expression levels of fatty acid binding protein 4 (FABP4), long-chain fatty acid CoA ligase 5 (ACSL5) and perilipin 2 (PLIN2) were measured by RT-qPCR (Figure 4B). The PPAR $\gamma$ Q286E mutation resulted in a significant increase in FABP4 expression and slight increases in the levels of ACLS5 and PLIN2 (Figure 4B). Along with our biophysical and biochemical analyses, the cell-based assay clearly demonstrated that the PPAR $\gamma$ Q286E mutation constitutively increases the transcriptional activity of PPAR $\gamma$ via the stabilization of the active conformation and by promoting the recruitment of $\mathrm{RXR} \alpha$ and co-activators.

\subsection{The Activation of PPAR $\gamma$ Q286E Would Be Independent of Endogenous Ligands}

Since PPAR $\gamma$ is physiologically regulated by endogenous ligands, it is possible that the activation of PPAR $\gamma$ mutants would be induced upon binding to known endogenous PPAR $\gamma$ 
ligands. Thus, we implemented isothermal titration calorimetry (ITC) experiments to measure the binding affinities of PPAR $\gamma$ LBD WT and mutants for 15 -deoxy- $\Delta^{12,14}$-prostaglandin $\mathrm{J}_{2}$ (15d-PGJ2) and 13S-hydroxy-9Z,11E-octadecadienoic acid (13S-HODE), which are endogenous ligands with PPAR $\gamma$ agonism $[35,36]$. In the ITC experiments, the ligands at a concentration of $0.9 \mathrm{mM}$ were titrated into PPAR $\gamma$ LBD at concentrations ranging from $45 \mu \mathrm{M}$ to $60 \mu \mathrm{M}$ using 19 injections of $2 \mu \mathrm{L}$. PPAR $\gamma$ LBD WT exhibited $K_{\mathrm{D}}$ values of $51.0 \mu \mathrm{M}$ and $14.6 \mu \mathrm{M}$ for 15d-PGJ2 and 13S-HODE, respectively (Figure 5A,B). However, the binding affinity of PPAR $\gamma$ LBD Q286E for 15d-PGJ2 was not detected and for 13S-HODE was lower $\left(K_{\mathrm{D}}=45.0 \mu \mathrm{M}\right)$ than that of PPAR $\gamma$ LBD WT (Figure 5C,D), indicating that the PPAR $\gamma$ Q286E mutation attenuates the binding of endogenous ligands. When we compared the 15d-PGJ2- and 13S-HODE-bound PPAR $\gamma$ LBD structures (PDB ID: 2ZK1, 2VST) with our PPAR $\gamma$ Q286E mutant structure, the conformation of Glu286 could increase steric hindrance, reducing the binding affinities of endogenous ligands (Figure 5E). It was consistent with the decreased binding affinity of lobeglitazone for the PPAR $\gamma$ LBD Q286E mutant although PPAR $\gamma$ full agonist lobeglitazone still bound to the Q286E mutant with high affinity (Figure 2C). For the other helix H3 mutants, we also observed lower binding affinities and more steric clashes for 15d-PGJ2 and 13S-HODE than the PPAR $\gamma$ LBD WT (Figure 5F and Figure S9). Taken all together, although helix H3 mutations of PPAR $\gamma$ LBD found in cancers resulted in the attenuation of endogenous ligand binding due to steric hindrance, the PPAR $\gamma$ Q286E mutant could be potently activated regardless of ligand binding.

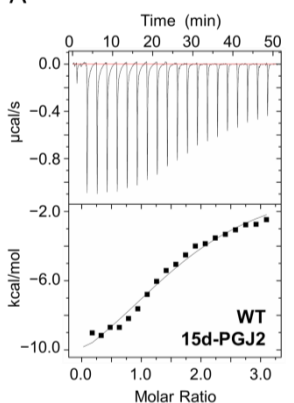

B

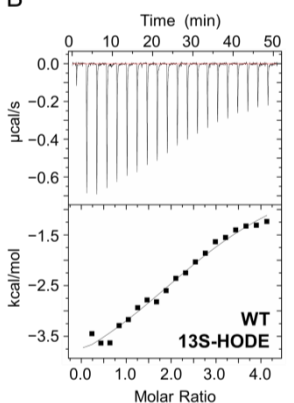

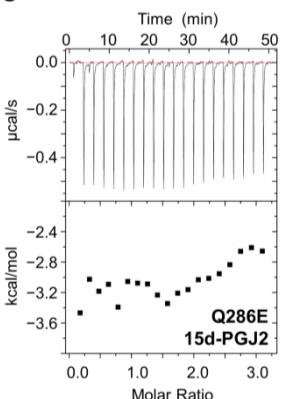

D

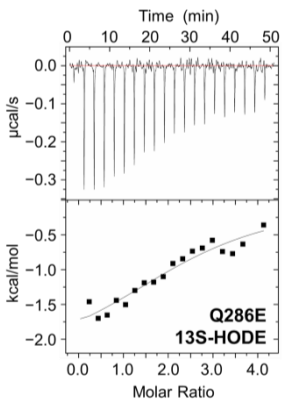

$\mathrm{E}$

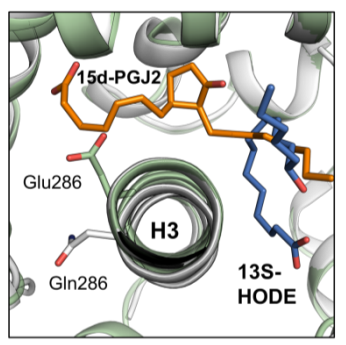

\begin{tabular}{c|cc}
\hline$K_{\mathrm{d}}$ & $15 \mathrm{~d}-\mathrm{PGJ}_{2}$ & $13 \mathrm{~S}-\mathrm{HODE}$ \\
\hline PPARY & 51.0 & 14.6 \\
\hline WT & 51.0 & $\mathrm{NB}$ \\
R280C & $\mathrm{NB}$ & 42.7 \\
C285Y & 162.3 & 45.9 \\
Q286E & NB & $\mathrm{NB}$ \\
Q286P & 201.2 & 27.7 \\
F287Y & 65.3 & $\mathrm{NB}$ \\
R288C & 8.3 & 67.1 \\
R288H & $\mathrm{NB}$ & $\mathrm{NB}$ \\
S289C & 42.9 & $(\mu \mathrm{M})$ \\
\hline & &
\end{tabular}

Figure 5. The binding affinity of PPAR $\gamma$ LBD for endogenous ligands. (A-D) ITC profiles for PPAR $\gamma$ LBD WT and Q286E with 15d-PGJ2 (A,C) and 13S-HODE (B,D). ITC analysis is conducted by titrating the endogenous ligands at a concentration of $0.9 \mathrm{mM}$ into PPAR $\gamma$ LBD proteins at concentrations ranging from $45 \mu \mathrm{M}$ to $60 \mu \mathrm{M}$. (E) Superposition of PPAR $\gamma$ LBD WT and Q286E structures with endogenous ligands of 15d-PGJ2 and 13S-HODE. The structures of PPAR $\gamma$ LBD WT and Q286E are shown as cartoon representations colored in white and pale green, respectively. The residues, Gln286 (white) and Glu286 (pale green) and the endogenous ligands, 15d-PGJ2 (orange) and HODE (blue), are displayed as stick representations. The ligands from the ligand-bound PPAR $\gamma$ LBD structures (PDB ID: 2ZK1, 2VST) are superposed onto the PPAR $\gamma$ LBD WT and Q286E structures. (F) $K_{\mathrm{D}}$ values are calculated from the fittings of the integrated molar heat upon added ligands and listed in table for $\operatorname{PPAR} \gamma$ LBD WT and mutants. 


\section{Discussion}

In this study, we characterized helix H3 mutations of PPAR $\gamma$ LBD found in various cancers. We identified PPARG mutations from publicly available genomic databases or cancer-related publications and evaluated the structure-function relationship. We found that the PPAR $\gamma$ Q286E mutation confers ligand-independent PPAR $\gamma$ activation by stabilizing the constitutively active conformation of PPAR $\gamma$, while PPAR $\gamma$ R280C, C285Y, Q286P, F287Y, R288C, R288H and S289C mutations are potential loss-of-function mutations in various aspects including ligand binding for PPAR $\gamma$ activation.

Although the exact roles of PPAR $\gamma$ in tumor microenvironments are still controversial, PPAR $\gamma$ is frequently regarded as a tumor suppressor, since numerous studies have shown that PPAR $\gamma$ transactivation by ligand binding induces inhibitory effects on tumor growth [12-15]. Considering the central role of helix $\mathrm{H} 3$ in ligand binding, $\operatorname{PPAR} \gamma$ mutations in this region could potentially reduce PPAR $\gamma$ activation by attenuating ligand binding. However, the PPAR $\gamma$ Q286E mutation found in bladder cancer increased PPAR $\gamma$ transactivation by inducing the active conformation, favoring the recruitment of $R X R \alpha$ and co-activators without ligand binding (Figures 2-5). It has recently been suggested that activation of the PPAR $\gamma / \mathrm{RXR} \alpha$ pathway via mutations in PPARG or RXRA promotes tumorigenesis in luminal bladder cancer [29,37]. The abnormal activation of the PPAR $\gamma / \operatorname{RXR} \alpha$ pathway decreases the activity of immune cell infiltration by inhibiting the expression and secretion of inflammatory factors, thereby hampering immunotherapies using immune checkpoint blockade in patients with cancer [30]. Indeed, several recurrent PPAR $\gamma$ mutations in luminal bladder cancer have been shown to induce the hyperactivation of PPAR $\gamma$ in a ligand-independent manner [25]. In a similar way, the PPAR $\gamma$ Q286E mutation in our study elicited transactivation regardless of ligand binding, thus supporting the pro-tumorigenic effects of PPAR $\gamma$ gain-of-function mutations in bladder cancer.

Transactivation by the PPAR $\gamma$ Q286E mutation could be explained by two structurally feasible mechanisms. First, the mutated Glu286 residue directly stabilizes the active conformation of PPAR $\gamma$ by forming a hydrogen bond with Tyr473 in helix H12 (Figure 2B). Full agonists bind to the ligand-binding pocket of PPAR $\gamma$ LBD, interact with Tyr473 via a hydrogen bond and stabilize helix H12 in the active conformation, which favors the recruitment of co-activators [38]. Similarly, the PPAR $\gamma$ Q286E mutation turns on the spontaneous recruitment of co-activators; it is worth noting that the PPAR $\gamma$ Q286E mutation is a distinct gain-of-function mutation as previously reported PPAR $\gamma$ recurrent T447M mutation (T475M in PPAR $\gamma$ isoform 2 numbering) directly stabilizing the active conformation of helix H12 [25]. Second, the structural stabilization of the $\Omega$-loop, helix H3 and H11-H12 loop observed in the PPAR $\gamma$ Q286E structure would indirectly favor the active conformation (Figure 2D and Figure S5). In some cases, PPAR $\gamma$ ligands such as partial agonists do not directly interact with helix H12 but induce the transactivation of PPAR $\gamma$ [39-42]. These ligands have been suggested to indirectly elicit the transactivation of PPAR $\gamma$ by stabilizing the helix $\mathrm{H} 3$ and $\Omega$-loop via an alternate binding site. Interestingly, our PPAR $\gamma$ Q286E structure in the absence of ligands exhibited the structurally stabilized helix $\mathrm{H} 3$ and $\Omega$-loop because the $\Omega$-loop forms extensive interaction networks with the helix H3 and H11-H12 loop (Figure 2D). When we calculated the normalized B-factors of the PPAR $\gamma$ LBD WT and Q286E structures, the regions encompassing $\Omega$-loop, helix H3 and H11-H12 loop were more stable in the PPAR $\gamma$ LBD Q286E structure than in the PPAR $\gamma$ LBD WT structure (Figure S10). Thus, it would indirectly induce transactivation of the PPAR $\gamma$ Q286E mutant. Taken together, the novel structural aspects of the PPAR $\gamma$ LBD Q286E mutant could explain the PPAR $\gamma$ transactivation in a ligand-independent manner and the modulation of its pro-tumorigenic role in bladder cancer.

PPAR $\gamma$ mutations found in colon cancer have been reported to elicit various levels of PPAR $\gamma$ transcriptional activity [43]. However, our results showed that the helix H3 mutations of PPAR $\gamma$ LBD found in colon cancers, including PPAR $\gamma$ C285Y, Q286P, R288H and S289C mutations, exhibited lower binding affinities for endogenous ligands such as 15d-PGJ2 and 13S-HODE [35,36,44,45] (Figure 5F). Moreover, the PPAR $\gamma$ R288H mutation elicited lower binding affinity for RXR $\alpha$ and PPAR $\gamma$ Q286P and S289C mutations exhibited lower binding affinities for MED1 co-activator (Figure 3). Taken all together, the helix H3 mutations of PPAR $\gamma$ LBD found in colon cancers would be loss-of-function mutations that 
reduce transcriptional activity of PPAR $\gamma$. In addition to colon cancer-associated mutations, PPAR $\gamma$ R280C and R288C found in uterine and skin cancers reduced the transcriptional activity of PPAR $\gamma$ and resulted in remarkably weak binding affinities for RXR $\alpha$ and MED1 co-activators (Figures 3 and 4). PPAR $\gamma$ R280C and R288C mutations also seemed to inhibit the binding of endogenous ligands such as 15d-PGJ2 and 13S-HODE (Figure 5F). Collectively, the helix H3 mutations of PPAR $\gamma$ LBD found in various cancers disrupt the sophisticated ligand-binding systems of PPAR $\gamma$, induce abnormal regulation of PPAR $\gamma$ transactivation and thus may affect tumor development or progression as loss-of-function mutations of PPAR $\gamma$.

Recently, inhibition of PPAR $\gamma$ Ser245 phosphorylation by noncanonical agonist PPAR $\gamma$ ligands has been shown to deregulate tumor-suppressor p53 signaling, sensitizing cancer cells to cytotoxic chemotherapy [46]. Considering that phosphorylation levels of PPAR $\gamma$ Ser245 are regulated by various ligands, the reduced ligand binding from the PPAR $\gamma$ helix H3 mutations including Q286E might increase the phosphorylation level of PPAR $\gamma$ Ser245, resulting in cancer cell survival through the dysregulation of p53 signaling. Likewise, cancer-associated mutations in combination with various endogenous ligands might complicate PPAR $\gamma$-dependent tumor microenvironment for different cancers, which should be further elucidated. In addition to PPAR $\gamma$, the other PPAR subtypes PPAR $\alpha$ and PPAR $\delta$ have been also reported to play important roles in regulating cancer cell growth [47-50]. As a number of mutations in the other PPAR subtypes have been discovered in various cancers, our approach using structure-function analyses of cancer-associated mutations could be applied for the other PPAR subtypes, which will expand PPAR researches in the tumor microenvironment.

\section{Materials and Methods}

\subsection{Cloning, Expression and Mutagenesis}

The cloning, expression, purification and crystallization of human PPAR $\gamma$ LBD were mainly performed as previously reported [39]. In brief, PPAR $\gamma$ LBD (residues 195-477 in PPAR $\gamma 1$ numbering) was cloned into the expression vector pET-28b(+) (Novagen, Darmstadt, Germany) between Nde1 and Xho1 restriction sites containing an N-terminal His ${ }_{6}$ tag (MGSSHHHHHHSSGLVPRGSH) and a thrombin cleavage site. The resulting recombinant PPAR $\gamma$ LBD proteins were overexpressed in Escherichia coli Rosetta 2(DE3) strain. Mutants of human PPAR $\gamma$ LBD in helix H3 region, including R280C, C285Y, Q286E, Q286P, F287Y, R288C, R288H and S289C, were generated by PCR (polymerase chain reaction)-based site-directed mutagenesis using PrimeSTAR ${ }^{\circledR}$ HS DNA polymerase (Takara Bio Inc., Kusatsu, Japan) and the mutations were confirmed by DNA sequencing.

\subsection{Purification}

The cells containing recombinant PPAR $\gamma$ LBD WT or mutants were grown at $37{ }^{\circ} \mathrm{C}$ in Luria-Bertani broth media containing $30 \mu \mathrm{g} / \mathrm{mL}$ kanamycin and induced by $0.5 \mathrm{mM}$ isopropyl 1 -thio- $\beta$-D-galactopyranoside at an OD600 of 0.6 and then incubated for additional $18 \mathrm{~h}$ at $20^{\circ} \mathrm{C}$. The cells were harvested by centrifugation at $6000 \times g$ for $10 \mathrm{~min}$ and lysed by sonication in buffer $\mathrm{A}(20$ $\mathrm{mM}$ Tris- $\mathrm{HCl} \mathrm{pH} 8.5,150 \mathrm{mM} \mathrm{NaCl}, 5 \mathrm{mM}$ imidazole, $10 \%(v / v)$ glycerol, $1 \mathrm{mM}$ TCEP) containing 1 $\mathrm{mM}$ phenylmethanesulfonylfluoride. The lysates were centrifuged at $35,000 \times g$ for an hour and the supernatants were filtered using a $0.45 \mu \mathrm{m}$ syringe filter device (Sartorius, Göttingen, Germany). For an affinity chromatography, the supernatants were loaded onto $5 \mathrm{~mL}$ HiTrap chelating HP column (GE Healthcare, Chicago, IL, USA) that was pre-charged with $\mathrm{Ni}^{2+}$ and equilibrated with buffer $\mathrm{A}$. Upon eluting with a linear gradient of buffer B $(20 \mathrm{mM}$ Tris- $\mathrm{HCl}$ pH 8.5, $150 \mathrm{mM} \mathrm{NaCl}, 300 \mathrm{mM}$ imidazole, 10\% (v/v) glycerol, $1 \mathrm{mM}$ TCEP), PPAR $\gamma$ LBD proteins were eluted at 50-100 mM imidazole concentrations. After the eluted proteins were desalted using HiPrep Desalting column 26/10 (GE Healthcare) to buffer C (20 mM Tris- $\mathrm{HCl}$ pH 8.5, $150 \mathrm{mM} \mathrm{NaCl}, 10 \%$ (v/v) glycerol, $1 \mathrm{mM}$ TCEP), the proteins were treated with thrombin (Sigma-Aldrich, Darmstadt, Germany) at $1 \mathrm{unit} / \mathrm{mg}$ and incubated at $4{ }^{\circ} \mathrm{C}$ overnight for the cleavage of $\mathrm{His}_{6}$-tags. The $\mathrm{His}_{6}$-tag-cleaved PPAR $\gamma$ LBD proteins were 
purified from the $\mathrm{His}_{6}$-tags by passing through the $\mathrm{Ni}^{2+}$ charged HiTrap chelating HP column and applied on a gel filtration chromatography column of HiLoad 16/600 Superdex200 pg (GE Healthcare) which was previously equilibrated with buffer C. For crystallization, the purified PPAR $\gamma$ LBD proteins were concentrated to $15.5 \mathrm{mg} / \mathrm{mL}$ using an Amicon Ultra-15 Centrifugal Filter Unit (Merck Millipore, Darmstadt, Germany). The recombinant PPAR $\gamma$ LBD mutants of R280C, C285Y, Q286E, Q286P, F287Y, R288C, R288H and S289C were expressed and purified in the same manner as the WT protein.

\subsection{Crystallization and X-Ray Data Collection}

The crystals of PPAR $\gamma$ LBD mutants in the presence of SRC-1 peptide (ERHKILHRLLQEGSPS) were grown by the sitting-drop vapor diffusion method at $22{ }^{\circ} \mathrm{C}$ by mixing equal volumes $(0.5 \mu \mathrm{L})$ of PPAR $\gamma$ LBD protein and crystallization solution containing $2.2 \mathrm{M}$ sodium malonate $\mathrm{pH}$ 7.0. The crystals of PPAR $\gamma$ LBD Q286E and R280C in the absence of a SRC-1 peptide were grown by mixing equal volumes $(0.5 \mu \mathrm{L})$ of protein and crystallization solution containing $1.4 \mathrm{M}$ sodium citrate tribasic dihydrate (Hampton Research, Aliso Viejo, CA, USA) and 0.1 M HEPES pH 7.5. Crystals that are suitable for data collection were grown in the presence of micro-seeds that were made from initial crystals of PPAR $\gamma$ LBD WT using Seed Bead ${ }^{\mathrm{TM}}$ (Hampton Research) according to the manufacturer's instructions. X-ray diffraction data for PPAR $\gamma$ LBD mutants were collected at $100 \mathrm{~K}$ in BL-5C and BL-7A experimental stations at Pohang Light Source, Korea and in PF-1A and PF-NE3A experimental stations at Photon Factory, Japan. All data were processed and scaled using HKL2000 [51]. Crystals of PPAR $\gamma$ LBD mutants in the presence of SRC-1 peptide belong to the space group of $P 2{ }_{1} 2_{1} 2$ and crystals of PPAR $\gamma$ LBD mutants in the absence of SRC-1 peptide belong to the space group $C 2$, with similar cell parameters of PPAR $\gamma$ LBD WT. Data collection statistics are summarized in Table S1.

\subsection{Structure Determination and Refinement}

The mutant structures were determined by molecular replacement with the previously published ligand-free PPAR $\gamma$ LBD WT structure models (PDB ID: 5GTP for peptide-bound structures; PDB ID: 6L8B for peptide-unbound structures) using MolRep [52]. The structures were refined by iterative manual buildings using Coot [53] and Refmac5 [54] in the CCP4 program suite. All refinement steps were monitored using $R_{\text {free }}$-values [55] based on excluded reflections, and reliabilities of refined models were evaluated using MolProbity [56]. The statistics for refinements are summarized in Table S1.

\subsection{Surface Plasmon Resonance}

The binding affinities of PPAR $\gamma$ LBD with lobeglitazone, RXR $\alpha$ and MED1 were investigated by SPR kinetics experiments. All SPR experiments were conducted at $25^{\circ} \mathrm{C}$ in a Biacore T200 system (GE Healthcare). For immobilization, an amine coupling kit containing $0.1 \mathrm{M} \mathrm{N}$-hydroxysuccinimide and 0.4 M 1-ethyl-3-(3-dimethylaminopropyl) carbodiimide hydrochloride on a CM5 sensor chip with HBS-EP (HEPES-buffered saline with EDTA and surfactant P20) buffer (10 mM HEPES pH 7.5, 150 $\mathrm{mM} \mathrm{NaCl}, 3 \mathrm{mM}$ EDTA, $0.005 \%$ tween 20 ) was used according to the manufacturer's protocol (GE Healthcare). For binding affinity measurements between PPAR $\gamma$ LBD and lobeglitazone, $30 \mu \mathrm{g} / \mathrm{mL}$ PPAR $\gamma$ LBD WT or Q286E mutant dissolved in $10 \mathrm{mM}$ sodium acetate at pH 5.0 were injected until the immobilization level reached approximately 3500 response units (RU) on the flow cell 2 or 4, respectively. The remaining activated carboxyl groups on the CM5 sensor chip surface were deactivated with $1 \mathrm{M}$ ethanolamine at $\mathrm{pH} 8.5$ for $400 \mathrm{~s}$. The control experiment was treated identically with reference flow cell 1 or 3 without proteins and the response by the control was subtracted from each sample dataset. Lobeglitazone at concentrations of $78.12 \mathrm{nM}, 156.25 \mathrm{nM}, 312.5 \mathrm{nM}, 625 \mathrm{nM}$ and 1.25 $\mu \mathrm{M}$ in PBS (phosphate-buffered saline) buffer containing 5\% (v/v) DMSO and 0.005\% (v/v) Tween 20 was injected over the flow cell 1 to 4 at a rate of $30 \mu \mathrm{L} / \mathrm{min}$ for $120 \mathrm{~s}$, followed by dissociation for $600 \mathrm{~s}$ in multi-cycle reactions. The sensor chip surface was regenerated for $5 \mathrm{~s}$ with $5 \mathrm{mM} \mathrm{NaOH}$ between cycles. For binding affinity measurements between PPAR $\gamma$ LBD and RXR $\alpha$ LBD, $5 \mu \mathrm{g} / \mathrm{mL}$ RXR $\alpha$ LBD 
dissolved in $10 \mathrm{mM}$ sodium acetate at $\mathrm{pH} 5.0$ were injected until the immobilization level reached approximately 600 RU. PPAR $\gamma$ LBD WT and mutants (R280C, C285Y, Q286E, Q286P, F287Y, R288C, $\mathrm{R} 288 \mathrm{H}$ and S289C) at concentrations of $3.125 \mathrm{nM}, 6.25 \mathrm{nM}, 12.5 \mathrm{nM}, 25 \mathrm{nM}, 50 \mathrm{nM}, 100 \mathrm{nM}$ and 200 $\mathrm{nM}$ in the buffer of $50 \mathrm{mM}$ Tris- $\mathrm{HCl}$ at $\mathrm{pH} 7.5,150 \mathrm{mM} \mathrm{NaCl}, 1 \mathrm{mM} \mathrm{TCEP}, 0.005 \%(v / v)$ tween 20 were injected over the chip at a rate of $30 \mu \mathrm{L} / \mathrm{min}$ for $120 \mathrm{~s}$, followed by dissociation for $500 \mathrm{~s}$ in multi-cycle reactions without regenerations between cycles. For binding affinity measurements between PPAR $\gamma$ LBD and MED1 peptide, $100 \mu \mathrm{g} / \mathrm{mL}$ MED1 peptide dissolved in $10 \mathrm{mM}$ sodium acetate at pH 5.5 were injected until the immobilization level reached approximately 60 RU. PPAR $\gamma$ LBD WT and mutants (R280C, C285Y, Q286E, Q286P, F287Y, R288C, R288H and S289C) at concentrations of $78 \mathrm{nM}, 156 \mathrm{nM}$, $312 \mathrm{nM}, 625 \mathrm{nM}, 1.25 \mu \mathrm{M}, 2.5 \mu \mathrm{M}, 5 \mu \mathrm{M}$ and $10 \mu \mathrm{M}$ in the buffer of $50 \mathrm{mM}$ Tris- $\mathrm{HCl}$ at $\mathrm{pH} 7.5,150 \mathrm{mM}$ $\mathrm{NaCl}, 1 \mathrm{mM}$ TCEP, $0.005 \%(v / v)$ tween 20 were injected over the chip at a rate of $30 \mu \mathrm{L} / \mathrm{min}$ for 120 $\mathrm{s}$, followed by dissociation for $400 \mathrm{~s}$ in multi-cycle reactions without regenerations between cycles. The SPR response data were fit to the simple bimolecular 1:1 Langmuir isotherm binding model to determine the equilibrium dissociation constant $\left(K_{\mathrm{D}}\right)$ using Biacore T200 evaluation software 3.0 (GE Healthcare).

\subsection{Luciferase Reporter Gene Assay}

HEK293T cells were cultured in Dulbecco Modified Eagles' Medium (DMEM; glucose $1 \mathrm{~g} / \mathrm{L}$ ) supplemented with $10 \%$ fetal bovine serum and $1 \%(v / v)$ penicillin and streptomycin. Cells were grown to $80 \%$ confluency at $37{ }^{\circ} \mathrm{C}$ under an atmosphere containing $5 \% \mathrm{CO}_{2}$ and then plated in 96-well plates (10,000 cells per well). For luciferase assays, HEK293T cells were transfected with $50 \mathrm{ng}$ pcDNA3-PPAR $\gamma$ WT or mutants (R280C, C285Y, Q286E, Q286P, F287Y, R288C, R288H and S289C), 70 ng PPRE-X3-TK-luc (1015; Bruce Spiegelman, Addgene, Cambridge, MA, USA) and 10 ng pRL-SV40 (Promega, Wallisellen, Switzerland) using Lipofectamine 2000 (Invitrogen, Carlsbad, CA) in opti-MEM according to the manufacturer's instruction. The media were changed to the culture media after $4 \mathrm{~h}$ and the cells were incubated for additional $48 \mathrm{~h}$. Luciferase activity was determined using Dual-Glo ${ }^{\circledR}$ Luciferase Assay System 2000 (Promega), according to the manufacturer's instruction and the resulting signals were normalized with Renilla luciferase signals obtained from pRL-SV40 plasmids. Relative luciferase units were plotted.

\subsection{Total RNA Isolation and Quantitative Real-Time PCR}

The total RNA samples in HEK293T cells containing the expression vectors for PPAR $\gamma$ WT and Q286E mutant were isolated using TRIzol (Thermo Fisher Scientific, Waltham, MA, USA). Reverse transcription was conducted with $1 \mu \mathrm{g}$ of total RNA using Moloney Murine Leukemia Virus (M-MLV) Reverse Transcriptase (Promega). Real-time quantitative PCR was performed with an Applied Biosystems 7500 Fast Real-Time PCR Instrument System (Thermo Fisher Scientific) using RealHelix Premier Quantitative PCR Kit (NanoHelix Co. Ltd., Deajeon, Korea) and primer pairs as follows: PLIN2: forward primer-TGTTAACAACACGCCCCTCA; reverse primer-ATGCTCAGATCGCTGGGGTCT; ACSL5: forward primer-TAGCTTCGGGTGTGTCCCAG; reverse primer-CCCTCACAGCTGGCTGTATT; FABP4: forward primer-TGGGCCAGGAATTTGACGAA; reverse primer-CACATGTACCAGGACACCCC. The identity of PCR products was verified using the dissociation curve analysis. Target gene expression was normalized to the gene of human L32. Data were analyzed by the comparative cycle threshold $\left(\Delta \Delta C_{t}\right)$ method.

\subsection{Isothermal Titration Calorimetry}

Binding affinities of PPAR $\gamma$ LBD WT and mutants (R280C, C285Y, Q286E, Q286P, F287Y, R288C, R288H and S289C) for 15-deoxy- $\Delta^{12,14}$-prostaglandin J2 (15d-PGJ2, Sigma Aldrich) and 13S-hydroxy-9Z,11E-octadecadienoic acid (13S-HODE, Cayman Chemical, Ann Arbor, MI, USA) were measured using a MicroCal ITC200 system (Malvern Instruments, Worcestershire, UK). All the 
measurements were conducted in the buffer of PBS pH 7.2 at $25^{\circ} \mathrm{C}$. The ligands filled in the syringe were titrated into the proteins in the cell using 19 injections of $2 \mu \mathrm{L}$ and an initial injection of $0.4 \mu \mathrm{L}$ with $150 \mathrm{~s}$ equilibration between injections. The final protein concentrations of PPAR $\gamma$ LBD WT and mutants were $60 \mu \mathrm{M}$ for 15d-PGJ2 at the ligand concentration of $900 \mu \mathrm{M}$ and $45 \mu \mathrm{M}$ for 13S-HODE at the ligand concentration of $900 \mu \mathrm{M}$, respectively. The obtained data were analyzed using Origin 7.0 software.

\subsection{Data Availability}

Atomic coordinates and structure factors for the structures of PPAR $\gamma$ LBD C285Y, Q286E, F287Y, R288C, R288H and S289C in presence of SRC-1 peptide and the structures of PPAR $\gamma$ LBD R280C and Q286E in the absence of SRC-1 peptide have been deposited in Protein Data Bank under the accession codes 7CXF, 7CXH, 7CXI, 7CXJ, 7CXK, 7CXL, 7CXE and 7CXG, respectively.

The mutation datasets in this study are available in The Cancer Genome Atlas (http: //cancergenome.nih.gov), International Cancer Genome Consortium (http://dcc.icgc.org), cBioPortal (http://www.cbioportal.org), and Catalogue Of Somatic Mutations In Cancer (http://cancer.sanger.ac. $\mathrm{uk} /$ cosmic) servers.

\section{Conclusions}

In the context of the rapid accumulation of cancer-related information about genetic alterations in PPARG, our systematic analyses on the structure-function relationships of cancer-associated PPAR $\gamma$ mutations enriched in helix $\mathrm{H} 3$ would provide a quantitative approach to predict cancer development and progression. In addition to the representative PPAR $\gamma$ research methods adopted in this study, further investigations of the physiological mechanisms by which PPAR $\gamma$ mutations influence the tumor microenvironment are needed. Our extensive characterization of cancer-associated mutations in helix H3 of PPAR $\gamma$ LBD provides a stepping stone for the development of new biomarkers targeting tumor microenvironments and a new therapeutic approach that pharmacologically inhibits the abnormal activation of PPAR $\gamma / \mathrm{RXR} \alpha$ pathway observed in certain cancers.

Supplementary Materials: The following are available online at http://www.mdpi.com/2072-6694/12/12/3580/s1, Figure S1: Magnified images of the mutated residues from the PPAR $\gamma$ LBD helix H3 mutants, Figure S2: Overall structures of PPAR $\gamma$ LBD WT and mutants, Figure S3: CD spectra of PPAR $\gamma$ LBD WT, Q286E and Q286P, Figure S4: Overall structures of PPAR $\gamma$ LBD WT and Q286E in the absence of a SRC-1 peptide, Figure S5: Close-up view of the interaction network among helix H3, $\Omega$-loop and H11-H12 loop in the structure of PPAR $\gamma$ LBD Q286E, Figure S6: Structural comparison of PPAR $\gamma$ LBD WT (PDB ID: 6L8B) (colored in white) and Q286E (colored in salmon) in the absence of a SRC-1 peptide, Figure S7: Sensorgrams for the summary (Figure 3C) showing the binding affinity between RXR $\alpha$ LBD and PPAR $\gamma$ LBD, Figure S8: Sensorgrams for the summary (Figure 3F) showing the binding affinity between a MED1 peptide and PPAR $\gamma$ LBD, Figure S9: Superposition of the mutated residues in PPAR $\gamma$ LBD helix $\mathrm{H} 3$ and known PPAR $\gamma$ endogenous ligands from reported complex structures, Figure S10: Normalized B-factor comparison between PPAR $\gamma$ LBD WT and Q286E structures, Table S1: Statistics for the data collection and model refinement, Table S2: Cancer-associated helix H3 mutations of PPAR $\gamma$ LBD.

Author Contributions: Conceptualization, D.M.J., J.Y.J. and B.W.H.; investigation, D.M.J. and J.Y.J.; data curation, D.M.J.; writing—original draft preparation, D.M.J. and J.Y.J.; writing—review and editing, D.M.J., H.-J.K. and B.W.H.; visualization, D.M.J.; supervision, B.W.H.; funding acquisition, B.W.H. All authors have read and agreed to the published version of the manuscript.

Funding: This work was supported by the Tumor Microenvironment Global Core Research Center (grant no. 2011-0030001) and the Basic Science Research Programs (grant no. NRF-2019R1A2C1090251) funded by the National Research Foundation (NRF) of the Ministry of Science and ICT of Korea. This work was also supported by Brain Korea (BK21) PLUS program to College of Pharmacy at Seoul National University. J.Y.J. was supported by the Basic Science Research Program (grant no. NRF-2020R1I1A1A01071874) funded by the NRF of the Ministry of Education of Korea.

Acknowledgments: We thank staffs at Pohang Accelerate Laboratory (Korea) and Photon Factory (Japan) for X-ray crystallography experiments.

Conflicts of Interest: The authors declare no conflict of interest. 


\section{References}

1. Gallastegui, N.; Mackinnon, J.A.; Fletterick, R.J.; Estebanez-Perpina, E. Advances in our structural understanding of orphan nuclear receptors. Trends Biochem. Sci. 2015, 40, 25-35. [CrossRef]

2. Berger, J.; Moller, D.E. The mechanisms of action of PPARs. Annu. Rev. Med. 2002, 53, 409-435. [CrossRef] [PubMed]

3. Fajas, L.; Auboeuf, D.; Raspe, E.; Schoonjans, K.; Lefebvre, A.M.; Saladin, R.; Najib, J.; Laville, M.; Fruchart, J.C.; Deeb, S.; et al. The organization, promoter analysis, and expression of the human PPARgamma gene. J. Biol. Chem. 1997, 272, 18779-18789. [CrossRef] [PubMed]

4. Ricote, M.; Huang, J.; Fajas, L.; Li, A.; Welch, J.; Najib, J.; Witztum, J.L.; Auwerx, J.; Palinski, W.; Glass, C.K. Expression of the peroxisome proliferator-activated receptor gamma (PPARgamma) in human atherosclerosis and regulation in macrophages by colony stimulating factors and oxidized low density lipoprotein. Proc. Natl. Acad. Sci. USA 1998, 95, 7614-7619. [CrossRef] [PubMed]

5. Lehrke, M.; Lazar, M.A. The many faces of PPARgamma. Cell 2005, 123, 993-999. [CrossRef]

6. Nesto, R.W.; Bell, D.; Bonow, R.O.; Fonseca, V.; Grundy, S.M.; Horton, E.S.; Le Winter, M.; Porte, D.; Semenkovich, C.F.; Smith, S.; et al. Thiazolidinedione use, fluid retention, and congestive heart failure: A consensus statement from the American Heart Association and American Diabetes Association. October 7, 2003. Circulation 2003, 108, 2941-2948. [CrossRef]

7. Berger, J.P.; Akiyama, T.E.; Meinke, P.T. PPARs: Therapeutic targets for metabolic disease. Trends Pharmacol. Sci. 2005, 26, 244-251. [CrossRef]

8. Wei, W.; Wan, Y. Thiazolidinediones on PPARgamma: The Roles in Bone Remodeling. PPAR Res. 2011, 2011, 867180. [CrossRef]

9. Panigrahy, D.; Huang, S.; Kieran, M.W.; Kaipainen, A. PPARgamma as a therapeutic target for tumor angiogenesis and metastasis. Cancer Biol. Ther. 2005, 4, 687-693. [CrossRef]

10. Reddy, A.T.; Lakshmi, S.P.; Reddy, R.C. PPARgamma as a Novel Therapeutic Target in Lung Cancer. PPAR Res. 2016, 2016, 8972570. [CrossRef]

11. Begum, N.M.; Nakashiro, K.; Kawamata, H.; Uchida, D.; Shintani, S.; Ikawa, Y.; Sato, M.; Hamakawa, H. Expression of peroxisome proliferator-activated receptor gamma and the growth inhibitory effect of its synthetic ligands in human salivary gland cancer cell lines. Int. J. Oncol. 2002, 20, 599-605. [PubMed]

12. Vella, V.; Nicolosi, M.L.; Giuliano, S.; Bellomo, M.; Belfiore, A.; Malaguarnera, R. PPAR-gamma Agonists As Antineoplastic Agents in Cancers with Dysregulated IGF Axis. Front. Endocrinol. (Lausanne) 2017, 8, 31. [CrossRef] [PubMed]

13. Elstner, E.; Muller, C.; Koshizuka, K.; Williamson, E.A.; Park, D.; Asou, H.; Shintaku, P.; Said, J.W.; Heber, D.; Koeffler, H.P. Ligands for peroxisome proliferator-activated receptorgamma and retinoic acid receptor inhibit growth and induce apoptosis of human breast cancer cells in vitro and in BNX mice. Proc. Natl. Acad. Sci. USA 1998, 95, 8806-8811. [CrossRef] [PubMed]

14. Yang, F.G.; Zhang, Z.W.; Xin, D.Q.; Shi, C.J.; Wu, J.P.; Guo, Y.L.; Guan, Y.F. Peroxisome proliferator-activated receptor gamma ligands induce cell cycle arrest and apoptosis in human renal carcinoma cell lines. Acta Pharmacol. Sin. 2005, 26, 753-761. [CrossRef] [PubMed]

15. Fujimura, S.; Suzumiya, J.; Nakamura, K.; Ono, J. Effects of troglitazone on the growth and differentiation of hematopoietic cell lines. Int. J. Oncol. 1998, 13, 1263-1267. [CrossRef] [PubMed]

16. Panigrahy, D.; Singer, S.; Shen, L.Q.; Butterfield, C.E.; Freedman, D.A.; Chen, E.J.; Moses, M.A.; Kilroy, S.; Duensing, S.; Fletcher, C.; et al. PPARgamma ligands inhibit primary tumor growth and metastasis by inhibiting angiogenesis. J. Clin. Investig. 2002, 110, 923-932. [CrossRef] [PubMed]

17. Aljada, A.; O'Connor, L.; Fu, Y.Y.; Mousa, S.A. PPAR gamma ligands, rosiglitazone and pioglitazone, inhibit bFGF- and VEGF-mediated angiogenesis. Angiogenesis 2008, 11, 361-367. [CrossRef]

18. Dang, Y.F.; Jiang, X.N.; Gong, F.L.; Guo, X.L. New insights into molecular mechanisms of rosiglitazone in monotherapy or combination therapy against cancers. Chem. Biol. Interact. 2018, 296, 162-170. [CrossRef]

19. Cao, L.Q.; Wang, X.L.; Wang, Q.; Xue, P.; Jiao, X.Y.; Peng, H.P.; Lu, H.W.; Zheng, Q.; Chen, X.L.; Huang, X.H.; et al. Rosiglitazone sensitizes hepatocellular carcinoma cell lines to 5-fluorouracil antitumor activity through activation of the PPARgamma signaling pathway. Acta Pharmacol. Sin. 2009, 30, 1316-1322. [CrossRef] 
20. Sun, W.H.; Chen, G.S.; Ou, X.L.; Yang, Y.; Luo, C.; Zhang, Y.; Shao, Y.; Xu, H.C.; Xiao, B.; Xue, Y.P.; et al. Inhibition of COX-2 and activation of peroxisome proliferator-activated receptor gamma synergistically inhibits proliferation and induces apoptosis of human pancreatic carcinoma cells. Cancer Lett. 2009, 275, 247-255. [CrossRef]

21. Neeraja, D.; Engel, B.J.; Carson, D.D. Activated EGFR stimulates MUC1 expression in human uterine and pancreatic cancer cell lines. J. Cell. Biochem. 2013, 114, 2314-2322. [CrossRef] [PubMed]

22. Bonofiglio, D.; Gabriele, S.; Aquila, S.; Qi, H.; Belmonte, M.; Catalano, S.; Ando, S. Peroxisome proliferator-activated receptor gamma activates fas ligand gene promoter inducing apoptosis in human breast cancer cells. Breast Cancer Res. Treat. 2009, 113, 423-434. [CrossRef] [PubMed]

23. Hatton, J.L.; Yee, L.D. Clinical Use of PPARgamma Ligands in Cancer. PPAR Res. 2008, $2008,159415$. [CrossRef] [PubMed]

24. Sarraf, P.; Mueller, E.; Smith, W.M.; Wright, H.M.; Kum, J.B.; Aaltonen, L.A.; de la Chapelle, A.; Spiegelman, B.M.; Eng, C. Loss-of-function mutations in PPAR gamma associated with human colon cancer. Mol. Cell 1999, 3, 799-804. [CrossRef]

25. Rochel, N.; Krucker, C.; Coutos-Thevenot, L.; Osz, J.; Zhang, R.; Guyon, E.; Zita, W.; Vanthong, S.; Hernandez, O.A.; Bourguet, M.; et al. Recurrent activating mutations of PPARgamma associated with luminal bladder tumors. Nat. Commun. 2019, 10, 253. [CrossRef] [PubMed]

26. Michalik, L.; Desvergne, B.; Wahli, W. Peroxisome-proliferator-activated receptors and cancers: Complex stories. Nat. Rev. Cancer 2004, 4, 61-70. [CrossRef] [PubMed]

27. Patel, L.; Pass, I.; Coxon, P.; Downes, C.P.; Smith, S.A.; Macphee, C.H. Tumor suppressor and anti-inflammatory actions of PPARgamma agonists are mediated via upregulation of PTEN. Curr. Biol. 2001, 11, 764-768. [CrossRef]

28. Capaccio, D.; Ciccodicola, A.; Sabatino, L.; Casamassimi, A.; Pancione, M.; Fucci, A.; Febbraro, A.; Merlino, A.; Graziano, G.; Colantuoni, V. A novel germline mutation in peroxisome proliferator-activated receptor gamma gene associated with large intestine polyp formation and dyslipidemia. Biochim. Biophys. Acta 2010, 1802, 572-581. [CrossRef]

29. Goldstein, J.T.; Berger, A.C.; Shih, J.; Duke, F.F.; Furst, L.; Kwiatkowski, D.J.; Cherniack, A.D.; Meyerson, M.; Strathdee, C.A. Genomic Activation of PPARG Reveals a Candidate Therapeutic Axis in Bladder Cancer. Cancer Res. 2017, 77, 6987-6998. [CrossRef]

30. Korpal, M.; Puyang, X.; Jeremy Wu, Z.; Seiler, R.; Furman, C.; Oo, H.Z.; Seiler, M.; Irwin, S.; Subramanian, V.; Julie Joshi, J.; et al. Evasion of immunosurveillance by genomic alterations of PPARgamma/RXRalpha in bladder cancer. Nat. Commun. 2017, 8, 103. [CrossRef]

31. Cerami, E.; Gao, J.; Dogrusoz, U.; Gross, B.E.; Sumer, S.O.; Aksoy, B.A.; Jacobsen, A.; Byrne, C.J.; Heuer, M.L.; Larsson, E.; et al. The cBio cancer genomics portal: An open platform for exploring multidimensional cancer genomics data. Cancer Discov. 2012, 2, 401-404. [CrossRef] [PubMed]

32. Gao, J.; Aksoy, B.A.; Dogrusoz, U.; Dresdner, G.; Gross, B.; Sumer, S.O.; Sun, Y.; Jacobsen, A.; Sinha, R.; Larsson, E.; et al. Integrative analysis of complex cancer genomics and clinical profiles using the cBioPortal. Sci. Signal. 2013, 6, pl1. [CrossRef] [PubMed]

33. Tate, J.G.; Bamford, S.; Jubb, H.C.; Sondka, Z.; Beare, D.M.; Bindal, N.; Boutselakis, H.; Cole, C.G.; Creatore, C.; Dawson, E.; et al. COSMIC: The Catalogue Of Somatic Mutations In Cancer. Nucleic Acids Res. 2019, 47, D941-D947. [CrossRef] [PubMed]

34. Jang, J.Y.; Bae, H.; Lee, Y.J.; Choi, Y.I.; Kim, H.J.; Park, S.B.; Suh, S.W.; Kim, S.W.; Han, B.W. Structural Basis for the Enhanced Anti-Diabetic Efficacy of Lobeglitazone on PPARgamma. Sci. Rep. 2018, 8, 31. [CrossRef]

35. Itoh, T.; Fairall, L.; Amin, K.; Inaba, Y.; Szanto, A.; Balint, B.L.; Nagy, L.; Yamamoto, K.; Schwabe, J.W. Structural basis for the activation of PPARgamma by oxidized fatty acids. Nat. Struct. Mol. Biol. 2008, 15, 924-931. [CrossRef]

36. Waku, T.; Shiraki, T.; Oyama, T.; Fujimoto, Y.; Maebara, K.; Kamiya, N.; Jingami, H.; Morikawa, K. Structural insight into PPARgamma activation through covalent modification with endogenous fatty acids. J. Mol. Biol. 2009, 385, 188-199. [CrossRef]

37. Halstead, A.M.; Kapadia, C.D.; Bolzenius, J.; Chu, C.E.; Schriefer, A.; Wartman, L.D.; Bowman, G.R.; Arora, V.K. Bladder-cancer-associated mutations in RXRA activate peroxisome proliferator-activated receptors to drive urothelial proliferation. eLife 2017, 6, e30862. [CrossRef] 
38. Nolte, R.T.; Wisely, G.B.; Westin, S.; Cobb, J.E.; Lambert, M.H.; Kurokawa, R.; Rosenfeld, M.G.; Willson, T.M.; Glass, C.K.; Milburn, M.V. Ligand binding and co-activator assembly of the peroxisome proliferator-activated receptor-gamma. Nature 1998, 395, 137-143. [CrossRef]

39. Ahn, S.; Jang, D.M.; Park, S.C.; An, S.; Shin, J.; Han, B.W.; Noh, M. Cyclin-Dependent Kinase 5 Inhibitor Butyrolactone I Elicits a Partial Agonist Activity of Peroxisome Proliferator-Activated Receptor gamma. Biomolecules 2020, 10, 275. [CrossRef]

40. Bruning, J.B.; Chalmers, M.J.; Prasad, S.; Busby, S.A.; Kamenecka, T.M.; He, Y.; Nettles, K.W.; Griffin, P.R. Partial agonists activate PPARgamma using a helix 12 independent mechanism. Structure 2007, 15, 1258-1271. [CrossRef]

41. Hughes, T.S.; Giri, P.K.; de Vera, I.M.; Marciano, D.P.; Kuruvilla, D.S.; Shin, Y.; Blayo, A.L.; Kamenecka, T.M.; Burris, T.P.; Griffin, P.R.; et al. An alternate binding site for PPARgamma ligands. Nat. Commun. 2014, 5, 3571. [CrossRef] [PubMed]

42. Jang, J.Y.; Koh, M.; Bae, H.; An, D.R.; Im, H.N.; Kim, H.S.; Yoon, J.Y.; Yoon, H.J.; Han, B.W.; Park, S.B.; et al. Structural basis for differential activities of enantiomeric PPARgamma agonists: Binding of S35 to the alternate site. Biochim. Biophys. Acta Proteins Proteom. 2017, 1865, 674-681. [CrossRef] [PubMed]

43. Broekema, M.F.; Massink, M.P.G.; Donato, C.; de Ligt, J.; Schaarschmidt, J.; Borgman, A.; Schooneman, M.G.; Melchers, D.; Gerding, M.N.; Houtman, R.; et al. Natural helix 9 mutants of PPARgamma differently affect its transcriptional activity. Mol. Metab. 2019, 20, 115-127. [CrossRef] [PubMed]

44. Nagy, L.; Tontonoz, P.; Alvarez, J.G.; Chen, H.; Evans, R.M. Oxidized LDL regulates macrophage gene expression through ligand activation of PPARgamma. Cell 1998, 93, 229-240. [CrossRef]

45. Li, J.; Guo, C.; Wu, J. 15-Deoxy-(12,14)-Prostaglandin J2 (15d-PGJ2), an Endogenous Ligand of PPAR-gamma: Function and Mechanism. PPAR Res. 2019, 2019, 7242030. [CrossRef] [PubMed]

46. Khandekar, M.J.; Banks, A.S.; Laznik-Bogoslavski, D.; White, J.P.; Choi, J.H.; Kazak, L.; Lo, J.C.; Cohen, P.; Wong, K.K.; Kamenecka, T.M.; et al. Noncanonical agonist PPARgamma ligands modulate the response to DNA damage and sensitize cancer cells to cytotoxic chemotherapy. Proc. Natl. Acad. Sci. USA 2018, 115, 561-566. [CrossRef]

47. Chen, Y.; Wang, Y.; Huang, Y.; Zeng, H.; Hu, B.; Guan, L.; Zhang, H.; Yu, A.M.; Johnson, C.H.; Gonzalez, F.J.; et al. PPARalpha regulates tumor cell proliferation and senescence via a novel target gene carnitine palmitoyltransferase 1C. Carcinogenesis 2017, 38, 474-483. [CrossRef] [PubMed]

48. Tachibana, K.; Yamasaki, D.; Ishimoto, K.; Doi, T. The Role of PPARs in Cancer. PPAR Res. 2008, $2008,102737$. [CrossRef] [PubMed]

49. Wagner, N.; Wagner, K.D. PPAR Beta/Delta and the Hallmarks of Cancer. Cells 2020, 9, 1133. [CrossRef]

50. Wang, X.; Wang, G.; Shi, Y.; Sun, L.; Gorczynski, R.; Li, Y.J.; Xu, Z.; Spaner, D.E. PPAR-delta promotes survival of breast cancer cells in harsh metabolic conditions. Oncogenesis 2016, 5, e232. [CrossRef]

51. Otwinowski, Z.; Minor, W. Processing of X-ray diffraction data collected in oscillation mode. Methods Enzymol. 1997, 276, 307-326. [PubMed]

52. Vagin, A.; Teplyakov, A. Molecular replacement with MOLREP. Acta Crystallogr. D Biol. Crystallogr. 2010, 66, 22-25. [CrossRef] [PubMed]

53. Emsley, P.; Lohkamp, B.; Scott, W.G.; Cowtan, K. Features and development of Coot. Acta Crystallogr. D Biol. Crystallogr. 2010, 66, 486-501. [CrossRef] [PubMed]

54. Murshudov, G.N.; Vagin, A.A.; Dodson, E.J. Refinement of macromolecular structures by the maximum-likelihood method. Acta Crystallogr. D Biol. Crystallogr. 1997, 53, 240-255. [CrossRef]

55. Brunger, A.T. Free R value: A novel statistical quantity for assessing the accuracy of crystal structures. Nature 1992, 355, 472-475. [CrossRef] 
56. Chen, V.B.; Arendall, W.B., 3rd; Headd, J.J.; Keedy, D.A.; Immormino, R.M.; Kapral, G.J.; Murray, L.W.; Richardson, J.S.; Richardson, D.C. MolProbity: All-atom structure validation for macromolecular crystallography. Acta Crystallogr. D Biol. Crystallogr. 2010, 66, 12-21. [CrossRef]

Publisher's Note: MDPI stays neutral with regard to jurisdictional claims in published maps and institutional affiliations.

(C) 2020 by the authors. Licensee MDPI, Basel, Switzerland. This article is an open access article distributed under the terms and conditions of the Creative Commons Attribution (CC BY) license (http://creativecommons.org/licenses/by/4.0/). 